\title{
More talk to help Europe's money
}

\section{Last week's contest for the leadership of Britain's Conservative party was a missed chance by both sides to say} what is right and wrong about plans for a common currency

BRITAIN's domestic contest for leadership of the Conservative party begun, last week, by an election by Conservative MPs in which the candidates were the prime minister, $\mathrm{Mr}$ John Major, and a previous member of his cabinet, Mr John Redwood, was driven by the strong opinion of many of the same MPs that Britain's integration into Europe has gone too far. It may therefore have been thought that the several days of debate preceding last Tuesday's vote would have at least clarified the issues from which discontent seems perennially to spring. But the opposite is the case. Redwood, the challenger in the election, dutifully said that a government of which he was the head would publicly set its face against membership of the proposed European currency system. The prime minister and his friends insist, as they have done since the negotiation of the Maastricht Treaty, that the time to decide is not now, but when the details of the common currency have been worked out. Neither side has said much to enlighten those who will vote in the general election there must be in less than two years.

That is a shabby and unconstructive way to carry on. The truth is that the question of the common currency is still undecided. Whatever the Maastricht Treaty says, there is no way in which other major members of the European Union (EU) than Britain will accept the proposals as they have been outlined. The central issue is not, of course, whether the local coinage should continue to carry representations of local dignitaries' heads, but whether Europe should now move towards a common monetary policy, and whether national fiscal policies should be subordinate to that larger framework. Germany has long been anxious that the plan will simply undermine its prudent management of its own currency in the past three decades. France also has second thoughts, as President Jacques Chirac told Major only the other day. And there is widespread disbelief that Italy will be able to reduce its annual budget deficit to less than 3 per cent of gross domestic product by the time the scheme is due to operate, perhaps in 1999.

The outline of the Maastricht scheme is simple. There is to be a European Monetary Institute that will function as a central bank independent of political control. Its function will be to manage monetary policy, in which the chief instrument is the determination of interest rates, for Europe as a whole. It would also become the lender of last resort to national governments. One danger in the system is that members of the EU choosing to operate with, say, grossly unbalanced budgets will be able to export the inflation such a practice would normally engender to the rest of Europe. To guard against that, Maastricht proposes a system by which countries would be fined by the central bank in a draconian way, which is politically unworkable. Another danger is that the system will be costly; relatively impoverished parts of Europe will qualify for regional aid, whereas, in a fully integrated economy, people would follow prosperity to other regions. A third is that national governments would be inhibited from using fiscal policy to cure domestic ills, unemployment for example.

Given these imponderables, it is natural that there should be general anxiety about the proposed quick march to a common currency. In many ways, it is foolhardy to pursue the goal without a better and wider understanding of how the difficulties would be overcome. That, in essence, is Chirac's point the other day. At least two courses might be followed. The Benelux members of the European Union appear to be anxious to get on with the project; why not encourage them to do so? That way, there would be some practical experience that might even encourage the others. But there is a more urgent need for more public talk about the details of a common currency. By sticking to broad generalities, the participants in last week's leadership election missed an opportunity that could only have strengthened their respective cases.

\section{More trade bilateralism}

On the heels of an aborted trade war with Japan, the United States is still hankering after bilateralism.

MORE by good luck than good management, the advertised trade dispute between the United States and Japan over their mutual trade in motor-cars and parts thereof has been averted. For practical purposes, the United States has accepted that it cannot ask the government of Japan to guarantee a predetermined volume of US exports every year, and has instead accepted the Japanese government's offer to remind its own traders of their freedom to sell US cars and components if they so wish. Plainly the outcome is neither that which the Clinton administration set out to secure, nor that which President Bill Clinton claimed in the aftermath of the negotiations. Will he and his advisers now appreciate that it might have been more effective to have followed the rules of the international trading system, and to have take 